This item was submitted to Loughborough's Research Repository by the author.

Items in Figshare are protected by copyright, with all rights reserved, unless otherwise indicated.

\title{
Balancing formality and informality in business exchanges as a duality: a comparative case study of returnee and local entrepreneurs in China
}

PLEASE CITE THE PUBLISHED VERSION

http://dx.doi.org/10.1017/mor.2014.2

\section{PUBLISHER}

Cambridge University Press (@ The International Association for Chinese Management Research)

\section{VERSION}

AM (Accepted Manuscript)

\section{PUBLISHER STATEMENT}

This work is made available according to the conditions of the Creative Commons Attribution-NonCommercialNoDerivatives 4.0 International (CC BY-NC-ND 4.0) licence. Full details of this licence are available at: https://creativecommons.org/licenses/by-nc-nd/4.0/

\section{LICENCE}

CC BY-NC-ND 4.0

\section{REPOSITORY RECORD}

Lin, Daomi, Jiangyong Lu, Peter Ping Li, and Xiaohui Liu. 2015. "Balancing Formality and Informality in Business Exchanges as a Duality: A Comparative Case Study of Returnee and Local Entrepreneurs in China". Loughborough University. https://hdl.handle.net/2134/18409. 
Balancing Formality and Informality in Business Exchanges as a Duality: A Comparative Case Study of Returnee and Local Entrepreneurs in China

\author{
Daomi Lin (林道㨫) \\ Sun Yat-sen University \\ China \\ Jiangyong Lu (路江涌) \\ Peking University \\ China \\ Peter Ping Li (李平) \\ Copenhagen Business School \\ Denmark \\ Xiaohui Liu (刘晓辉) \\ Loughborough University \\ UK
}




\title{
Balancing Formality and Informality in Business Exchanges as a Duality: A Comparative Case Study of Returnee and Local Entrepreneurs in China
}

\begin{abstract}
The management paradigms in the West mainly rely on legal contracts and explicit rules (formality), while the management traditions in the East emphasize social relationships and implicit norms (informality). In an era of 'West-meets-East', balancing formality and informality is becoming critical for firms, especially those facing institutional differences in transnational contexts and institutional transitions. In this study, we conducted a comparative multi-case study on returnee entrepreneurs and local entrepreneurs in China. We found that at the early stage of venturing returnee entrepreneurs emphasized formality more than informality, while local entrepreneurs stressed informality more than formality. However, the formality-informality balance among both returnee and local entrepreneurs converged over time in line with the institutional transition in China. Returnee entrepreneurs increased the emphasis on informality (but kept the dominant position of formality), whereas local entrepreneurs gradually shifted from informality to formality. The spatial pattern of asymmetrical balancing and the temporal pattern of transitional balancing are both rooted in the Chinese philosophy of Yin-Yang balancing.
\end{abstract}

Keywords: formality-informality balance, institutional differences and institutional dynamics, returnee and local entrepreneurship, Yin-Yang duality 
Running title: Balancing Formality and Informality 


\section{INTRODUCTION}

The rapid growth of emerging economies in the East and the increasing global integration of diverse economies have reshaped the business reality from the traditional context of 'West-leads-East' to a new one of 'West-meets-East' (Chen \& Miller, 2010). One important characteristic of the 'West-meets-East' era is that different institutions in the West and East interact more intensively than in the era of 'West-leads-East' through the global expansion of multinational enterprises (MNEs) and the more frequent human mobility across national borders. The past decade has witnessed an upsurge of new ventures initiated by entrepreneurs such as transnational entrepreneurs, ethnic entrepreneurs and returnee entrepreneurs who are exposed to a transnational context (Droi, Honig, \& Wright, 2009). Among them, returnee entrepreneurs, who typically have spent a considerable period of time in developed economies and then returned to their home countries, have become an important phenomenon in Eastern countries such as China, India, and Korea.

There are distinctions between returnee and local entrepreneurs. For example, returnee entrepreneurs tend to enjoy the advantage of being familiar with formality (e.g., technological capabilities) but suffer from the disadvantage of being weak in informal elements (e.g., local connections) (Li, Zhang, Li, Zhou, \& Zhang, 2012). It is also observed that returnee entrepreneurs prefer explicit rules, while local entrepreneurs are in favor of implicit norms. However, all entrepreneurs must combine both formal and informal elements to survive and grow, so the real question is how to balance the two seemingly conflicting elements (Cardinal, Sitkin, \& Long, 2004). In particular, we are interested in how returnee and local entrepreneurs 
differ when they balance formality and informality in their business exchanges given their distinctive preferences for formal or informal elements.

The notion of formality and informality is central to economic and social exchanges as two fundamental dimensions of the governance mode for both inter-firm and intra-firm transactions (Li, 2007) in such contexts as organization control (Cardinal et al., 2004), organization hierarchy (Diefenbach \& Sillince, 2011), social relations (Morand, 1995), and inter-firm collaborations (Zhang, Wan, Jia, \& Gu. 2009). The preference for formality refers to an emphasis on elements associated with impersonal exchange (e.g., legal contracts and explicit rules) over elements related to personal relationships (e.g., social relationships and implicit norms). The preference for informality is primarily shaped by the institutional context which comprises of both formal and informal institutions (North, 1990).

Prior literature has recognized the effect of the local institutional environment on entrepreneurs' cognition and behavior (Bruton, Ahlstrom, \& Li, 2010). However, most studies have focused on a single country's institutions without taking account of the increasing human mobility crossing national borders, limiting our understanding of institutions and entrepreneurship in transnational contexts. More specifically, we know little about how entrepreneurs' prior exposure to an institutional environment affects their management orientations in business exchanges when they start new ventures in a new institutional environment. Furthermore, organizational behavior co-evolves with the institutional transitions (e.g., Dieleman \& Sachs, 2006). This begs the question of whether firms with different initial managerial preferences for formality or informality in business transactions 
would converge or diverge over time as an economy evolves, especially in the context of dramatic institutional transition. Hence, our research focuses on two questions: (1) How do local and returnee entrepreneurs who have different prior exposures to the Western or Eastern institutional context balance formality and informality in their business exchanges when they start new ventures in their home country (i.e., China)? (2) How do local and returnee entrepreneurs shift their specific balances between formality and informality in their business exchanges over time?

Due to the paucity of theories on entrepreneurship in transnational contexts and dynamic institutional settings, we adopt the comparative multi-case study method (Eisenhardt, 1989). Using both qualitative and quantitative data, we compare how two groups of entrepreneurial firms (i.e., returnee and local firms) balance formality and informality in China at both the early and later stages of venturing.

The study seeks to make three contributions. First, we contribute to the transnational entrepreneurship literature by showing that entrepreneurs with prior exposure to different institutional contexts have different balances of formality and informality at the early stage of venturing. Over time, these firms in the same institutional context will converge to a similar formality-informality balance in business exchanges. Second, we contribute to the on-going debate of the formality-informality dichotomy as complementary or substitutive. Our study highlights that formal and informal elements are simultaneously complementary and substitutive, and the specific balances of the two elements are asymmetrical in a spatial pattern. Third, our study found that over time entrepreneurs increasingly emphasize synergy rather than 
tradeoff, resulting in a more moderate formality-informality balance, which is called transitional in a temporal pattern. The last two contributions evoke the Chinese philosophy of Yin-Yang balancing, explaining the flexibility in balancing formal and informal approaches with global implications for non-Chinese entrepreneurs.

\section{THEORETICAL BACKGROUND}

Formality refers to the nature of business exchanges as explicitly prescribed, exogenously imposed, and rigidly enforced by vertical authority powers in a universalistic and depersonalized process (e.g., objective, rational, task-oriented, and instrumental). Informality is implicitly assumed, endogenously embraced, and flexibly enforced by horizontal peer pressures in a particularistic and personalized process (e.g., subjective, non-rational, people-oriented, and sentimental) ( $\mathrm{Li}, 2007)$. Formality and informality can be reflected in various domains of business exchanges, including customer relationships, public relationships, and R\&D collaborative relationships, all of which are critical for new ventures (Brush, Greene, \& Hart, 2001).

Customer relationships stand for the orientation of market-based activities, which are fundamental to a firm's survival and growth (Day \& Montgomery, 1999). Formal customer relationships are rooted in transactional marketing, where the marketing activities focus on impersonal advantages of differentiated product features and low cost advantages (Coviello, Brodie, Danaher, \& Johnston, 2002). In contrast, informal customer relationships are based on relationship marketing, which emphasizes identifying, establishing, maintaining, and 
enhancing relationships with customers in an informal and personal way (Gronroos, 1990).

Public relationships represent a firm's non-market based activities, focusing on public stakeholders, such as governments, political groups, trade associations and communities, are important (Clarkson, 1995). A formal orientation denotes a strategic approach to maintaining public stakeholder relationships and conforming to prescribed, explicit codes through objectives and impersonal processes sanctioned by legal powers (Sharratt, Brigham \& Brigham, 2007). In contrast, firms with an informal orientation cultivate public stakeholder relationships through interpersonal processes sanctioned by social power (e.g., trust and reputation) and mutual interests (Khavul, Bruton, \& Wood, 2009).

R\&D collaborative relationships refer to how a firm engages and controls its R\&D partnership with other organizations, which is important for the firm to build sustainable competitive advantages in high-tech industries. Firms in favor of formal mechanisms in R\&D collaborations rely on hierarchical authority or detailed, explicit contractual specifications (Das \& Teng, 2001). Firms in favor of informal elements in R\&D collaborations emphasize social mechanisms and implicit mutual understanding (Jones, Hesterly, \& Borgatti, 1997).

Although prior studies have deepened our understanding about the importance of formality and informality in intra-firm and inter-firm relationships, our knowledge is still limited in several aspects. First, formal mechanisms dominate market exchanges (Peng, 2003) in Western developed economies, while informal mechanisms fill the voids of formal mechanisms in emerging markets (Hoskisson, Wright, Filatotchev, \& Peng, 2013). Such differences in institutional environments may influence the strategic approaches adopted by 
entrepreneurs in developed and emerging economies. However, it is unclear how entrepreneurs exposed to transnational institutions balance formality and informality in business exchanges. Second, while it is widely agreed that entrepreneurs' strategic decisions co-evolve with institutional environments (Peng \& Zhou, 2005), there is the question of how entrepreneurs with different levels of exposure to transnational contexts change their formal-informal balances over time. Further, there is an ongoing debate regarding whether the formality-informality balance is complementary (e.g., Cardinal et al., 2004; Li, 2007) or substitutive (e.g., North, 1990; Peng, 2003). The current research is to shed light on the nature of the formality-informality balance within the context of 'West meets East' and increasing mobility of returnees to China.

\section{METHOD}

We chose the comparative multi-case study method for two reasons. First, case studies allow researchers to develop a holistic understanding of real-life phenomena and are preferred when researchers attempt to understand complex social events. Second, comparative multi-case studies allow us to compare local entrepreneurs with returnee entrepreneurs, investigate the systematic differences between them and illustrate the dynamic changes of such differences.

Returnee and local entrepreneurs in Chinese high-tech industries provide an ideal research setting for understanding how entrepreneurs with different prior exposure to the Western or Eastern institutions manage customer relationships, public relationships, and $\mathrm{R} \& \mathrm{D}$ collaborative relationships through balancing formality and informality. To explore the 
differences between returnee and local entrepreneurs, we focused on the early stage of venturing. First, the early stage of venturing is critical because ventures are subject to the liability of newness and thus suffer from higher risk of failure (Bruderl \& Schussler, 1990). Second, after returning to their home country, returnee entrepreneurs face the challenges of readjusting to the local institutional environment (Gaw, 2000). Therefore, focusing on the early stage of venturing enables us to observe how returnee entrepreneurs balance formality and informality when they face the strong institutional differences. To explore the dynamic changes of returnee and local entrepreneurs, we compare the balance of formality and informality at the later stage with that at the early stage of venturing. We consider the first three years of a new venture as the early stage and subsequent years that as the later stage.

The study sample consists of six firms established by the alumni of a top university in China, including three from the biotech industry and three from the new energy industry. We chose these two industries for three reasons. First, both biotech and new energy industries are among the seven Strategic Emerging Industries identified by the Chinese central government. ${ }^{[1]}$ Thus, domestic institutions (e.g., industry policies) have important impacts on the survival and growth of firms in these industries. Second, the two industries are deeply integrated with the global market, and thus, firms in these industries are affected by institutions in developed countries. Third, the high demand of resources for firms in these two high-tech industries requires that entrepreneurs adapt to local institutional contexts and institutional changes. Thus, the chosen industries are an appropriate setting to examine the two research questions. In choosing returnee entrepreneurs, we focused on those who had spent a 
considerable period of time in developed economies. The founders of the three returnee firms had overseas experiences of 10,13, and 15 years, respectively, in the United States. Information on the sampled firms and their founders is in Table 1.

\section{INSERT TABLE 1 ABOUT HERE}

\section{Data Collection}

We relied on several data sources, including interviews, phone calls, e-mails, and archival data, such as internal documents, websites, and news articles. The triangulation of data sources provides accurate information and improves the reliability of the case findings (Anand, Gardner, \& Morris, 2007). The primary data source was 45 semi-structured interviews with open-ended questions during 2011 to 2013. We first interviewed highly knowledgeable informants who were founders or co-founders of the firms and then asked them to identify other informants who were directly involved in the entrepreneurship process. We interviewed at least 4 informants for each firm. All interviews were conducted in Chinese.

We used open-ended questions that gave the informants a wide scope to reveal the most important events regarding customer, public and R\&D collaborative relationships. To gain more complete information (Eisenhardt \& Graebner, 2007), we prompted the informants to provide more details when their descriptions were brief or when novel narrative strands emerged. The interviewees were asked to provide a comprehensive account of their actions related to the three domains at the early stage of their entrepreneurship. To control for recall biases, we asked the informants about the most important events in their entrepreneurship and asked other informants to confirm the information. All interviews were recorded and 
transcribed in Chinese, mostly within 24 hours.

We also used closed-ended questions to ask the entrepreneurs to evaluate the importance of formality and informality in the three domains. For example, the respondents were asked to provide a ratio of formal to informal mechanisms in managing customer relationships at the very beginning of entrepreneurship as well as at present. Using these quantitative data, we compared entrepreneurs' emphases on formal and informal mechanisms and dynamic shifts of the dominant mechanism over time.

We addressed potential informant biases in several ways. First, we interviewed various informants with different management positions in the sampled firms. Second, we used 'courtroom questioning' that focused on factual accounts of what informants did themselves or what the informants observed others did regarding customer relationships, public relationships and R\&D collaborations. We avoided asking informant speculative questions (e.g., 'Why did this transaction succeed'?). Third, we triangulated data from multiple informants and archival sources (Kumar, Stern, \& Anderson, 1993). Fourth, our informants were motivated to give accurate information because they were eager to know how they were different from their counterparts in managing entrepreneurial processes. Such strong interest among informants improved the accuracy of their accounts (Miller, Cardinal, \& Glick, 1997). We also promised confidentiality of their answers.

\section{Case Analysis}

We used within-case and cross-case analyses with no priori hypotheses (Eisenhardt \& 
Graebner, 2007). We began by writing individual cases based on interviews and archival data. We triangulated the data and focused on pre-conceived themes that received support from different data sources and that were agreed upon by the authors. We conducted a second round of interviews to fill in missing details. The transcript for each case was between 40 to 90 pages, including words, pictures and charts. Two of the authors reviewed the cases to form independent views and wrote notes. We then synthesized these views for each firm.

We then performed within-case analysis, taking a single firm as the unit of analysis. First, we coded the events, actions or interviewees' thoughts into three pre-conceived categories (i.e., the three domains of customer relationship, public relationship, and R\&D collaborative relationship). Then, we used open-coding to identify and illustrate each detailed process in plain language. One author and a trained Ph.D. student implemented this coding process separately and then convened to determine the categorization for axial coding. According to the definition and characteristics of formality and informality (Li, 2007; Misztal, 2002), we coded the processes of impersonal contacts, explicit rules, tight enforcement and hierarchical authorities as elements that fit the category of formality. We coded the processes of interpersonal contacts, implicitly shared-values, loose cooperation and social sanctions under the category of informality. The inter-coder agreement was $99 \%$ of all the items coded. The coding scheme is shown in Figure 1.

\section{INSERT FIGURE 1 ABOUT HERE}

We conducted cross-case analyses using replication logic across the sampled firms to perform a broad search for consistent patterns (Yin, 2003). We used tables to compare returnee 
and local firms, highlighting similarities and differences. For example, both returnee and local firms show different levels of effort to build personal relationships with potential customers as well as distinct differences in their efforts to market through explicit advantages in technologies or services. Returnee entrepreneurs expressed a relative emphasis on the objective advantages in product features, while local entrepreneurs expressed a relative focus on personal communication and relationship with potential customers. Using replication logic, we examined the patterns from some cases in the sample to develop preliminary relationships and then analyze the remaining cases to validate and refine the emergent theory.

Once our cross-case analysis was underway, we compared theory, case data, and the literature to refine the theoretical relationships (Glaser \& Strauss, 1967). We continued until we achieved a strong match between cases and theory in a coherent manner. Then, the quotes used in this study were translated into English.

\section{RESULTS}

\section{The Asymmetrical Pattern of Formality-Informality Balance}

For the first research question, 'how do local and returnee entrepreneurs who have different prior exposure to the Western or Eastern institutional context balance formality and informality in their business exchanges when they start new ventures in their home country (i.e., China)?', we explored how returnee and local entrepreneurs balanced formal and informal elements in the domains of customer, public and R\&D collaborative relationships at the early stage of entrepreneurship. Overall, the results showed that returnee entrepreneurs preferred formal to 
informal elements, but local entrepreneurs preferred informal to formal elements. Table 2 summarizes the case evidence in each of the three domains.

\section{INSERT TABLE 2 ABOUT HERE}

Customer relationships. In this domain, the case evidence clearly showed that while both returnee and local firms simultaneously used formal and informal mechanisms to acquire customers, they placed different emphasis on each. Returnee firms deemed formal elements, such as advocating the advantages of their products and using an impersonal process, as the dominant mechanisms to attract and retain customers. In contrast, local firms placed a strong emphasis on informal elements, such as building personal relationships and engaging in unofficial or informal contacts to manage a customer base.

R1-Energy, a returnee firm, mainly relied on its advanced business model to attract customers at the beginning. As the president recalled, 'It was our distinctive competitive advantage that earned us market shares. We emphasized our capability to provide integrated solutions to customers, which differentiated us from competitors'. Meanwhile, the firm also recruited local salesmen to access local customers through personal contacts. In comparing the importance of formal elements with that of informal elements, the president of R1-Energy gave a ratio of 9:1 (sum of 10). The percentages of transcripts coded as formal or informal elements in customer relationships for R1-Energy were $66.7 \%$ vs. $33.3 \%$.

L2-Energy, a local firm, placed a strong emphasis on informal elements in managing customer relationships. The president elaborated that 'I let every customer feel my affection and earnestness. Even after a deal was closed, I sent cards and messages to our customers 
during every important festival to maintain our friendships'. The local entrepreneur also hired experts and academic institutes to improve the firm's technologies. However, cultivating affection was considered the key factor by the president. He indicated a 4:6 ratio of the firm's effort in technology improvement to personal relationship building when the firm was founded. The percentages of transcripts coded as informal and formal elements in customer relationships for L2-Energy were $75.0 \%$ and $25.0 \%$, respectively.

Public relationships. In this domain, both returnee and local entrepreneurs realized the importance of obtaining support from public stakeholders through both formal and informal mechanisms. However, returnee entrepreneurs strived for stakeholders' support through open competition and passively complied with explicit regulations. In contrast, local entrepreneurs actively built personal connections with public stakeholders and embraced social obligations in informal ways.

R2-Biotech, a returnee firm, sought government support through open bidding based on explicit criteria. As the administrative director noted, 'The government would announce a bidding invitation. Then we would compete based on capability and be evaluated by a panel of industry experts'. Furthermore, R2-Biotech deemed capability as the key to governmental support and avoided close relationships with the government because 'it may distract our focus from innovation'. The president estimated the ratio of formal elements to informal elements in public relationships as 8:2. The percentages of transcripts coded as formal and informal elements in public relationships for R2-Energy were $72.7 \%$ and $27.3 \%$, respectively. 
L2-Energy, founded by a local entrepreneur, actively looked for support from the government and the local community through informal channels and shared values. The president utilized his personal connections and sent a report to the top-ranking officials, emphasizing the profound influence of the waste incineration industry and received positive feedback, which triggered a media upsurge advocating L2-Energy as a successful example. L2-Energy also invited one peasant per household to work in the factory to 'build $a$ harmonious community through the involvement of employees'. Moreover, the president of L2-Energy considered personal relationships to be the most critical factor in public relationships. His weight of emphasis on formal elements to informal elements in public relationships was 2:8. The percentages of transcripts coded as informal and formal elements in public relationships for L2-Energy were $88.9 \%$ and $11.1 \%$, respectively.

$R \& D$ collaborative relationships. In general, we found that although both returnee and local firms used formal and informal mechanisms to manage R\&D collaborations simultaneously, returnee firms relied more on hierarchical authorities and explicit, codified contracts, while local firms were more inclined to adopt social mechanisms based on interpersonal connections, trust and implicit agreements.

R3-Biotech, the returnee firm, kept most of its core technologies under internal hierarchies and formed ad-hoc collaborations based on profit maximization. As the CEO noted, 'We collaborated with others as long as each of us could benefit and gain a profit'. R3-Biotech also accessed technological information through informal meetings in industry alliances. However, 
formal elements played a dominant role in R\&D collaborations. The president rated the ratio of formal elements to informal elements in $R \& D$ collaborations as 6:4. The percentages of transcripts coded as formal and informal elements in R\&D collaborative relationships for R3-Biotech were $66.7 \%$ and $33.3 \%$, respectively.

The local firm L1-Energy mainly relied on personal connections and implicit agreements to manage R\&D collaborations at the early stage. L1-Energy cooperated with a top ranking institute by leveraging personal relationships. As the president said, 'At first, we were not competitive enough to collaborate with the top ranking institute. Fortunately, I knew an expert who was renowned and familiar with the principal of the institute... Without him, we could have never formed the alliance'. In addition, L1-Energy took advantage of implicit agreements. As the president noted, 'We named our product after the institute's name for the first two years. Actually, we didn't have any explicit agreements in our contract. But we considered it as an implicit agreement took advantages of this grey area'. Informal elements played a dominant role in L1-Energy's R\&D collaborations. The VP recalled that at the early stage of venturing, the ratio of informal elements to formal elements in governing $R \& D$ collaborations was 6:4. The percentages of transcripts coded as informal and formal elements in R\&D collaborative relationships for L1-Energy were $85.7 \%$ and $14.3 \%$, respectively.

Case evidence also showed that at the early stage of venturing, both returnee and local entrepreneurs viewed formal elements and informal elements as simultaneously complementary and substitutive in the three domains. On the one hand, formal and informal elements are considered indispensable and complementary. The president of R1-Energy 
suggested that 'Competences of the firm and informal relationships can facilitate each other and generate synergies. If you are strong in technological competence, people will consider you reliable, thus promoting customer relationships. If you have close relationships with customers, you can gain more opportunities to improve the firm's competence'. On the other hand, the entrepreneurs mentioned a partial substitution between formal and informal elements. As the president of R3-Biotech noted, 'While some issues could not be specified in a contract, basic consensus and a shared understanding could supplement to resolve the issues'. The VP of L1-Energy also mentioned, 'Sometimes when products are homogenous, trustworthy relationships with customers can be supplementary to achieve success'. Table 3 summarizes the case evidence about complementarity and substitution in each domain.

INSERT TABLE 3 ABOUT HERE

\section{The Transitional Pattern of Formality-Informality Balancing}

To answer our second research question, 'how do local and returnee entrepreneurs shift their specific balances between formality and informality in their business exchanges over time?', we compared the dynamic patterns of formal-informal balance adopted by the returnee and local firms in the three domains. We found that, over time, both returnee and local firms began to place a greater emphasis on formal elements. While the returnee firms placed increasing emphasis on informal elements, the local firms attached more importance to formal elements over time. Table 4 summarizes the case evidence in the three domains.

INSERT TABLE 4 ABOUT HERE 
Customer relationships. We found that returnee firms were more committed to informal elements such as building local sales teams and developing relationship marketing over time. In contrast, local firms increasingly adopted formal mechanisms, focusing on technology and product improvement.

R3-Biotech, a returnee firm, had been gradually hiring local people with local experience to communicate with potential customers. As the CEO mentioned, 'Returnees are not familiar with how to build interpersonal relationships with domestic customers. We are now recruiting a local sales team to do relationship marketing'. Moreover, while the CEO's rating of the importance of formal elements vs. informal elements for the year 2009 when the firm was founded was $7: 3$, the rating changed to $6: 4$ for 2013 . This change indicates that the returnee firm had strengthened the informal mechanisms to attract customers, but formal mechanisms still dominated in customer relationships.

In contrast, the local firm, L2-Energy, began to deliberately improve its operation efficiency after 2 years of development. The president stated: 'We relied on guanxi to attract customers before. But now we need to emphasize more the quality of our products and the superior operation model'. Moreover, the relative emphasis had shifted from informal to formal elements. The rating of the two elements in customer relationships was 4:6 for 2009 when the venture was founded, while the rating changed to 7:3 for 2013.

Public relationships. In the domain of public relationships, we observed that returnee entrepreneurs were beginning to build personal relationships and trust with public stakeholders 
through informal channels over time. Meanwhile, local entrepreneurs increasingly emphasized technology and product advantages to gain support from public stakeholders and shifted their focus from informality to formality.

The returnee firm, R1-Energy, had been engaged in social activities two years after their founding. In 2011, R1-Energy initiated and sponsored a top-class international new energy competition with the U.S. National Energy Administration and the Chinese government in order 'to build a socially responsible image'. However, they still maintained the dominant role of formal elements. As the president commented: 'Although the Chinese government may be influenced by "guanxi", eventually it needs to support firms with leading technologies as required by the regulations'. The president's rating of the ratio between the two mechanisms in public relationships had changed from 8:2 in 2009 to 7:3 in 2013, indicating that more attention had been paid to leverage informal elements, but formal elements still dominated.

The local firm, L1-Energy, had been increasingly investing in technology advantages to achieve governmental support six years after its founding. As the president stated, 'We have passed the government authentication and become one of the few national enterprise technology centers in the province'. The rating of formal-informal elements for public relationships changed from 4:6 in 2002 to 6:4 in 2013, indicating an increasing investment in formal elements and a shift toward dominance of formal elements.

$R \& D$ collaborative relationships. In this domain, we also found that returnee firms were more inclined to use social mechanisms, while local firms increasingly relied on authority and 
explicit contracts and shifted their relative emphasis from informal to formal elements.

R2-Biotech, a returnee firm, had intensified the role of social power (e.g., trust and reliability) in R\&D collaboration over time. For example, in collaboration with a hospital, the two parties communicated extensively and collaborated without contracts at the early stage because they both trusted the principal in the project. However, formal elements still played a dominant role. The president's rating of the importance of formal vs. informal elements in R\&D collaboration changed from 9:1 in 2007 to 7:3 in 2013.

Conversely, the local firm L2-Energy, which had been relying on interpersonal cooperation, started to emphasize explicit contracts and rules in $\mathrm{R} \& \mathrm{D}$ collaborations. The president of L2-Energy noted, 'In collaboration with a foreign institute, the main mechanism we used is contract and economic objectives'. In addition, the rating of the two elements in managing R\&D collaborations for L1-Energy changed from 4:6 in 2009 to 7:3 in 2013.

We also observed that as firms developed, both returnee and local firms aimed to achieve synergies through integrating the two elements, thus striving to attain a more balanced relationship between formal and informal elements than at the early stage of their venture development. For returnee firms, as the President of R3-Biotech suggested, 'Now we need to strengthen our local sales forces to build personal relationships with customers in order to complement product advantages'. Further evidence reveals that the increasing emphasis on informal elements is accompanied by accumulated trust and communication experience in adjusting to the Chinese context. For example, the administration director of R2-Bioteh said, 'Over time, the government had accumulated trust and familiarity with our firm, which can 
complement our technological capability to achieve governmental support'.

Similarly, local entrepreneurs integrated the two elements as they reinforced their investment in technological advantage. As the President of L2-Energy noted, 'it is not feasible to rely only on social sanctions. We need to use formal contracts to achieve common goals'. Moreover, local entrepreneurs realized that formal elements provide ultimate value in the relationship, especially in the transition toward a market-based economy. As the president of L3-Biotech mentioned, 'ultimately, customers are paying money to satisfy their needs'. Table 5 summaries the emphasis on synergy between the two sets of firms.

INSERT TABLE 5 ABOUT HERE

\section{DISCUSSION}

\section{Research Propositions}

The case evidence delineates two emerging patterns of the formality-informality balance. The first pattern (spatial) can be termed 'asymmetrical balancing', which relates to the first research question. At the early stage of venturing, both groups of entrepreneurs adopted formality and informality simultaneously in all the three domains with either formality or informality as dominant. Returnee entrepreneurs tended to emphasize formality over informality in an asymmetrical pattern, while the local entrepreneurs focused more on informality. For a general spatial pattern, we propose the new construct asymmetrical pattern of formal-informal balance and develop two propositions: 
Proposition 1a: At the early stage of venturing, returnee firms tend to balance formality and informality in their business exchanges in an asymmetrical pattern, with formality being the dominant element.

Proposition 1b: At the early stage of venturing, local firms tend to balance formality and informality in their business exchanges in an asymmetrical pattern, with informality being the dominant element.

This asymmetrical pattern derives primarily from the two different institutional contexts to which the two groups of entrepreneurs had been exposed prior to the start of venturing in China. Since returnee entrepreneurs were more exposed to the Western institutional context, they place the dominant focus on market-based rules and depersonalized processes. In contrast, local entrepreneurs are exposed to the Eastern institutional context at home, with a strong preference for informal processes and network-based strategies (Peng \& Heath, 1996). Existing studies have found that variation in formal institutions (e.g., regulations and laws) and informal institutions (e.g., values, norms, and social expectations) influences the governance of entrepreneurial firms, including how entrepreneurs acquire necessary resources and manage external relationships (Bruton et al., 2010; Welter, 2011). For example, Luo (2007) found that in international joint ventures, managers from individualist cultures tend to rely more on formal anti-opportunism mechanisms, while managers from collectivistic cultures tend to rely more on informal anti-opportunism mechanisms. Zhang et al. (2009) have shown that when the legal infrastructure for enforcing formal contracts is not effective, informal relationships such as guanxi play an indispensable and vital role in the successful operations of public-private partners in Chinese society. These findings have been further confirmed by Batjargal, Hitt, Tsui, Arregle, Webb, and Miller (2013). Their study revealed that entrepreneurs in weak and 
inefficient formal institutional contexts tend to use structural holes as a substitute for rules. This implies that entrepreneurs from different institutional contexts with varying degrees of formal and informal institutions may exhibit different preferences for formality or informality in managing transactions.

We further observed from the case evidence that formal and informal elements could be simultaneously complementary and substitutive. For a long time, many scholars regarded formal and informal elements as substitutes in the belief that the presence of one element obviates the need for the other (e.g., Larson, 1992). More recently, however, some scholars have begun to take formal and informal elements not as mutually exclusive but as complementary. It is argued that in situations with severe exchange hazard, the combination of formal and informal mechanisms may deliver better exchange performance than either orientation in isolation (Poppo \& Zender, 2002). This view is highly consistent with research on ambidexterity (O’Reilly \& Tushman, 2013; Raisch \& Birkinshaw, 2008). Differing from the above two views, the case evidence shows that both returnee and local entrepreneurs took formal and informal elements as partially complementary for synergy and also partially substitutive for tradeoff. This unique pattern of asymmetrical balancing represents a strategy above and beyond the debate of taking formal and informal elements as either a fully conflicting tradeoff or fully complementary synergy.

Contrary to the Western 'either/or' logic, this unique pattern is rooted in the traditional Chinese philosophy of asymmetrical balancing, the first operating mechanism of Yin-Yang balancing (Li, 2012b, 2014). It posits that the opposite elements are partially conflicting for 
partial tradeoff and partially complementary for partial synergy (相生相克 in Chinese). Therefore, they must adopt an asymmetrical pattern to maximize their partial synergy and minimize their partial tradeoff. The rationale for asymmetrical balancing is that opposite elements tend to be more complementary and less conflicting when one element is more dominant than the other; in contrast, opposite elements tend to be more conflicting and less complementary when both elements are equally dominant (Li, 2014).

The second pattern (temporal) can be termed 'transitional balancing', emerging from the evidence exclusively concerning the second research question. Over time, both types of firms converged gradually to a more moderate balance compared with the initial more asymmetrical balance. In particular, returnee entrepreneurs gradually changed the balance with an increasing emphasis on informal elements (with formal elements remaining the dominant), while local entrepreneurs gradually shifted towards a rebalance with a greater emphasis on formal elements (even to the extent that formal elements become the dominant pattern than the initial pattern). For a general temporal pattern, we propose the new construct transitional pattern of formal-informal balance and develop two propositions:

Proposition 2a: Over time, returnee firms tend to put increasing emphasis on informality in their business exchanges in a transitional pattern but are likely to continue keeping formality as the dominant element during this transition, resulting in a moderate asymmetrical balance.

Proposition 2b: Over time, local firms tend to put increasing emphasis on formality in their business exchanges in a transitional pattern and are likely to gradually adopt formality as the dominant element during this transition, resulting in a moderate asymmetrical balance.

The different dynamics of returnee and local firms in the same institutional context are 
likely a result of the joint effect of their prior institutional exposure and current institutional pressure. Previous studies have found that, over time, firms will be affected by the isomorphic mechanism of local institutions (Dimaggio \& Powell, 1983). For returnee entrepreneurs, the effect of exposure to the Western institutional context was more visible at the early stage of venturing. Once they have gradually established themselves in the local market and gained a deeper understanding about the local business norms and how their local peers manage business exchanges, they bend to conform to the local norms. Local firms coevolved with the institutional transitions in the emerging market (Peng, 2003). Emerging economies went through 'fundamental and comprehensive changes introduced to the institutional rules of the game that affect firms as players' (Peng, 2003: 275), which are collectively known as "institutional transitions" and which favor economic liberalization and the adoption of free-market systems (Meyer \& Peng, 2005). China has been aiming to build a rule-based market system incorporating international best practice institutions since implementing the reform and opening policy. These transitions include government decentralization, the privatization of State-Owned Enterprises (SOEs), and conformity to international uniform rules. Previous studies have found that in institutional changes toward rule-based economies in emerging markets, such as China, firms operating there tend to shift from a personalized to a depersonalized mode (Dieleman \& Sachs, 2006; Hoskisson, Eden, Lau, \& Wright, 2000). Consistent with the prior literature, we observed that formal elements have become increasingly important in local firms in parallel with the advance of formal institutions in China. However, China’s economic transition is incomplete (Hoskisson et al., 2013), and local 
connections or guanxi are still important (Li, Zhang, \& Lyles, 2013). Hence, returnee entrepreneurs who had been exposed to the West with a higher degree of formality still need to strengthen informality to conform to the institutional context in the emerging market. The above discussion suggests that the impact of prior institutional exposure can fade over time, while current institutional exposure may trigger the isomorphic change of all firms to converge to a similar pattern.

Another insight from the case evidence is the increasing emphasis on synergies between formality and informality as both groups of firms grow. At a later stage of venturing, both returnee and local firms tend to emphasize synergy by integrating formal and informal elements rather than tradeoff by substituting one for another. In particular, returnee firms tried to complement formal elements with informal elements as they accumulated more experience and adapted to the strong informal institutions in the local context. In contrast, local firms increasingly emphasized formal elements to complement informal elements as they realized the essence of market economy principles and gradually adjust their conformity in the institutional transition toward a rule-based economy. In other words, the increasing demand for synergies is another driving force for the change of formal-informal balance, complementary to the institutional pressure. However, most of the local firms not only placed stronger emphasis on formality but also shifted from an informality-dominant balancing to a formality-dominant balancing. This shift implies that the institutional transition toward a rule-based economy pushed local firms to adopt formal elements as their dominant approach. The dynamic capability of Chinese entrepreneurs in reacting to the institutional environment flexibly and 
shifting between formal and informal elements effortlessly is rooted in the Chinese philosophy of transitional balancing, the second operating mechanism of Yin-Yang balancing (Li, 2012b, 2014). This operating mechanism is based on the same principle of having both partial tradeoff and partial synergy as the inner source of mutual transitions, which are often triggered by the dramatic changes in the external context. This insight further suggests that a moderate asymmetrical balance is more desirable as firms grow.

\section{Alternative Explanations}

As in all research, there may be alternative explanations that may undermine the proposed argument. First, the different patterns we observed between returnee and local entrepreneurs could be attributed to pre-existing individual differences. However, the sampled firms in the study were mainly established by alumni of a top university in China. Although there may exist some variations in personal characteristics, such pre-existing differences could be relatively small given that they all were educated in the same university before some of them went abroad. Further, we observed a case among the sampled firms (L3-Biotech) which showed some serious conflicts between the local founder and one of his college classmates who joined the company after studying and working overseas for several years. Our interviews with the local founder and his partner clearly showed that the conflicts were not caused by pre-existed differences in the past but by their later exposure to different institutional environments. A second possible explanation is that the cohort effect (i.e., the year of founding) affects firms' formal-informal balance patterns. This may offer insights into the experiences of L1-Energy 
and L3-Biotech because both were founded in the 2000s, when China was still at the stage of network-based economies. However, this assumption cannot explain the strong preference for informality by L2-Energy, which was founded in 2009, when China was undergoing a transition towards rule-based economies for more than 30 years. Therefore, the cohort effect cannot explain the systematic differences in our sample.

A third explanation for the different patterns between returnee and local firms is the different resource endowments due to different levels of exposure to developed or emerging economies. Returnee entrepreneurs may have technological advantages that provide the foundation for a formal approach in business exchanges, while local entrepreneurs may have stronger social networks in home countries to support informal mechanisms. This explanation may complement our institutional explanation because firms need to pursue legitimacy and efficiency; the former is affected by exogenous institutions, whereas the latter is influenced by internal resources. As shown in the case evidence, the asymmetrical pattern is mainly attributed to the prior institutional exposure. In addition, we observed that returnees also had social relationships in China, although not as extensive as local entrepreneurs. The reason for their preference is not the quantity or quality of social ties, but the fact that returnee entrepreneurs did not want to or did not know how to utilize their personal relationships at the early stage of their return. In summary, we admit that resource endowments due to different levels of institutional exposure is a possible endogenous explanation, complementary to the explanation of the institutional context.

Finally, the accumulation of resources over time in the local institutional environment also 
can be an endogenous explanation for the transitional pattern of returnee and local firms. For example, over time returnee entrepreneurs could have expanded their social networks and become more experienced in how to apply those ties, so they appear to increasingly emphasize informal elements. However, this assumption cannot explain the dynamic shift from informality to formality among the local firms. Therefore, the explanation of the co-evolution with the institutional transition toward a rule-based economy is still necessary to explain the pattern. In this sense, we acknowledge the accumulation of resources over time as a complementary explanation for the temporal pattern of formal-informal balance, but this cannot substitute for the effect of the local institutional context.

\section{Theoretical Contributions}

This study makes three contributions. First, it contributes to the transnational entrepreneurship literature by exploring the effect of entrepreneurs' prior exposure to different institutional contexts on new ventures' formal-informal balance as they establish ventures in their original home countries and its convergence in accordance with the evolution of domestic institutions over time. Although prior research has demonstrated the effect of local institutions on entrepreneurs (Bruton et al., 2010), our study goes one step further by examining the influence of prior exposure to the institutional context. Second, the study contributes to the formality-informality literature by highlighting the idea of asymmetrical balancing. The third contribution is the insight that the balance between formality and informality is a dynamic rather than a static process, thus the need for transitional balancing. 
The last two contributions have critical implications for institutional research and paradox management. Specifically, the two contributions directly challenge the long-standing debate over the relationship between formal and informal elements in terms of framing them from the perspective of "either/or" logic, which treats the link between opposites as either fully conflicting or fully complementary in all spatial aspects and at all temporal stages (Smith \& Lewis, 2011). In this study, however, we not only found that formality and informality can be partially complementary and partially substitutive but also found that firms tend to shift toward synergy rather than tradeoff as they grow. In other words, the formality-informality link is both conflicting and complementary in all aspects and at all times because, like all pairs of opposite elements, it should be taken as a duality (defined as opposites-in-unity for partial synergy and partial tradeoff, or 相生相克 in Chinese) in need of holistic and dynamic balances. This fundamental insight is rooted in the Yin-Yang balance (Fang, 2012; Jing \& Van de Ven, 2014; Li, 2008, 2012a, 2012b, 2014).

\section{Limitations}

We acknowledge some limitations of our study. First, the sampled returnees came from one host country (i.e., the United States). Future studies could sample two groups of returnee entrepreneurs from different host countries with different formal-informal institutions (e.g., Japan, where informal elements play important roles, and the United States, where formal elements dominate) to examine whether returnee entrepreneurs' preferences still depend on prior institutional exposure (i.e., Japan and the United States). Second, Although all the six 
firms are in rapid growth and good financial statues during the time of our interviews, which indicates that these firms may benefit from asymmetrical and transitional balancing, we did not have their specific performance information to draw conclusions about the impact of the formality-informality balance on performance. It would be interesting to explicitly study the performance consequence of asymmetrical and transitional balancing. Third, we only observed the trend of change; we did not reveal the speed of the transitions. It is valuable to conduct longitudinal studies to reveal detailed dynamic patterns of entrepreneurship, including both pattern, and speed, in a transnational and transitional context. Finally, our findings are based on case evidence from a single emerging economy. Because returnee and local entrepreneurship in emerging economies is a global phenomenon, future research should be extended to other emerging economies to explore either the generalizability of the findings from this study or to reveal variances in different institutional environments and institutional dynamics. Lastly, we focus on firms founded by either returnee or local entrepreneurs. This does not allow us to understand the patterns of formality and informality in ventures founded by partnership between returnee and local entrepreneurs.

\section{Managerial Implications}

The findings from the study have a number of managerial implications for entrepreneurs and managers. First, both returnee and local entrepreneurs would benefit from knowing how to achieve a proper balance between formal and informal elements to effectively manage business exchanges. Specifically, returnee entrepreneurs may want to devote greater effort into 
developing mutually beneficial relationships with stakeholders in emerging markets. For local entrepreneurs, establishing internal technological capability is crucial when the business environment evolves from a more relationship-based to a more market-based system where technological advantage is important. Second, entrepreneurs operating in emerging markets should consider the merit of a more balanced perspective. The frame of Yin-Yang balancing can help entrepreneurs and managers to appreciate management tension and turn paradoxical tension into balanced outcomes. Finally, the findings suggest that returnee and local entrepreneurs can learn from each other and cooperate to utilize their complementary capability. More specifically, returnee entrepreneurs can learn from local entrepreneurs to utilize informal mechanisms, while local entrepreneurs can gain insights from returnee entrepreneurs to enhance their utilization of formal mechanisms. They, as some already do, may form mutually beneficial partnerships as co-founders of new ventures. However, we offer this implication with some trepidation because such ventures also may incur conflict due to vastly different logic between the two types of entrepreneurs. Research is needed to understand such partnership ventures.

\section{CONCLUSION}

In the contexts of 'West-meets-East' and globalization, we have explored both the distinctions and similarities between returnee and local entrepreneurs to enrich our knowledge about entrepreneurship in a transnational context as well as their dynamic co-evolution with institutional contexts. Focusing on the balance between formality and informality at the early 
stage of venturing and its evolution over time by comparing returnee and local entrepreneurs in emerging economies using a comparative case study method, we have addressed two critical research gaps on how entrepreneurs with different exposure to the Western and the Eastern institutional contexts balance formal and informal elements at the early stage of venturing and how the shift in such balances occurs over time. The critical theoretical and practical implications of this study are associated with the Eastern frame of Yin-Yang balancing. More indigenous research would be desirable to shed additional insights into other phenomena related to management and entrepreneurship embedded in the interaction between Eastern and Western perspectives under the theme of 'West-meets-East'.

\section{NOTES}

The paper was partially funded by research grants from the National Science Foundation of China (\#71172020) and Guanghua-Cisco Leadership Institute.

[1] The seven strategic emerging industries include energy-saving and environmental protection, information technology, biology, advanced equipment manufacturing, new energy, new materials and new-energy vehicles.

\section{REFERENCES:}

Anand, N., Gardner, H. K., \& Morris, T. 2007. Knowledge-based innovation: Emergence and embedding of new practice areas in management consulting firms. Academy of Management Journal, 50(2): 406-428.

Batjargal, B. A. T., Hitt, M. A., Tsui, A. S., Arregle, J.-L., Webb, J. W., \& Miller, T. L. 2013. Institutional polycentrism, entrepreneurs' social networks, and new venture growth. Academy of Management Journal, 56(4): 1024-1049.

Bruderl, J., \& Schussler, R. 1990. Organizational mortality: The liabilities of newness and adolescence. Administrative Science Quarterly, 530-547. 
Brush, C. G., Greene, P. G., \& Hart, M. M. 2001. From initial idea to unique advantage: The entrepreneurial challenge of constructing a resource base. The Academy of Management Executive, 15(1): 64-78.

Bruton, G. D., Ahlstrom, D., \& Li, H. L. 2010. Institutional theory and entrepreneurship: Where are we now and where do we need to move in the future? Entrepreneurship Theory and Practice, 34(3): 421-440.

Cardinal, L. B., Sitkin, S. B., \& Long, C. P. 2004. Balancing and rebalancing in the creation and evolution of organizational control. Organization Science, 15: 411-431.

Chen, M.-J., \& Miller, D. 2010. West meets East: Toward an ambicultural approach to management. Academy of Management Perspectives, 24(4): 17-24.

Clarkson, M. B. E. 1995. A stakeholder framework for analyzing and evaluating corporate social performance. Academy of Management Review, 20(1): 92-117.

Coviello, N. E., Brodie, R. J., Danaher, P. J., \& Johnston, W. J. 2002. How firms relate to their markets: An empirical examination of contemporary marketing practices. Journal of Marketing, 66(3): 33-46.

Das, T. K., \& Teng, B.-S. 2001. Trust, control, and risk in strategic alliances: An integrated framework. Organization studies, 22(2): 251-283.

Day, G. S., \& Montgomery, D. B. 1999. Charting new directions for marketing. The Journal of Marketing: 3-13.

Diefenbach, T., \& Sillince, J. A. A. 2011. Formal and informal hierarchy in different types of organization. Organization Studies, 32(11): 1515-1537.

Dieleman, M., \& Sachs, W. 2006. Oscillating between a relationship-based and a market-based model: The Salim Group. Asia Pacific Journal of Management, 23(4): 521-536.

DiMaggio, P. J., \& Powell, W. W. 2000. The iron cage revisited institutional isomorphism and collective rationality in organizational fields. Advances in strategic management, 17: 143-166.

Drori, I., Honig, B., \& Wright, M. 2009. Transnational entrepreneurship: An emergent field of study. Entrepreneurship: Theory and Practice, 33(5): 1001-1022.

Eisenhardt, K. M. 1989. Building theories from case-study research. Academy of Management Review, 14(4): 532-550.

Eisenhardt, K. M., \& Graebner, M. E. 2007. Theory building from cases: Opportunities and challenges. Academy of Management Journal, 50(1): 25-32.

Fang, T. 2012. Yin Yang: A new perspective on culture. Management and Organization Review, 8(1): 25-50.

Gaw, K. F. 2000. Reverse culture shock in students returning from overseas. International Journal of Intercultural Relations, 24(1): 83-104.

Glaser, B. G., \& Strauss, A. L. 2009. The Discovery of Grounded theory: Strategies for Qualitative Research: Transaction Books.

Gronroos, C. 1990. Relationship approach to marketing in service contexts: The marketing and organizational behavior interface. Journal of Business Research, 20(1): 3-11.

Hoskisson, R., Eden, L., Lau, C. M., \& Wright, M. 2000. Strategy in emerging economies. Academy of Management Journal, 43(3): 249-267. 
Hoskisson, R., Wright, M., Filatotchev, I. \& Peng, M. 2013. Emerging multinationals from mid-range economies: The influence of institutions and factor markets. Journal of Management Studies, forthcoming.

Jing, R-T. \& Van de Ven, A. 2014. A Yin-Yang model of organizational change: The case of CBG. Management and Organization Review, 10(1) (in press).

Jones, C., Hesterly, W. S., \& Borgatti, S. P. 1997. A general theory of network governance: Exchange conditions and social mechanisms. Academy of Management Review, 22(4): 911-945.

Khavul, S., Bruton, G. D., \& Wood, E. 2009. Informal family business in Africa. Entrepreneurship Theory and Practice, 33(6): 1219-1238.

Kumar, N., Stern, L. W., \& Anderson, J. C. 1993. Conducting inter-organizational research using key informants. Academy of Management Journal, 36(6): 1633-1651.

Larson, A. 1992. Network dyads in entrepreneurial settings - A study of the governance of exchange relationships. Administrative Science Quarterly, 37(1): 76-104.

Li, H.Y., Zhang, Y. \& Lyles, M. 2013. Knowledge Spillovers, Search, and Creation in China's Emerging Market, Management and Organization Review, 9(3): 395-412.

Li, P. P. 2007. Social tie, social capital, and social behavior: Toward an integrative model of informal exchange. Asia Pacific Journal of Management, 24(2): 227-246.

Li, P. P. 2008. Toward a geocentric framework of trust: An application to organizational trust. Management and Organization Review, 4(3): 413-439.

Li, P. P. 2012a. Toward an integrative framework of indigenous research: The geocentric implications of Yin-Yang Balance. Asia Pacific Journal of Management, 29(4): 849-872.

Li, P. P. 2012b. Exploring the unique roles of trust and play in private creativity: From the complexity-ambiguity-metaphor link to the trust-play-creativity link. Journal of Trust Research, 2 (1): 71-97.

Li, P.P. 2014. The unique value of Yin-Yang Balancing: A critical response. Management and Organization Review, 10(2) (in press).

Li, H., Zhang, Y., Li, Y., Zhou, L.-A., \& Zhang, W. 2012. Returnees versus locals: Who perform better in China's technology entrepreneurship? Strategic Entrepreneurship Journal, 6(3): 257-272.

Luo, Y. D. 2007. An integrated anti-opportunism system in international exchange. Journal of International Business Studies, 38(6): 855-877.

Meyer, K. E., \& Peng, M. W. 2005. Probing theoretically into Central and Eastern Europe: transactions, resources, and institutions. Journal of International Business Studies, 36(6): 600-621.

Miller, C. C., Cardinal, L. B., \& Glick, W. H. 1997. Retrospective reports in organizational research: A reexamination of recent evidence. Academy of Management Journal, 40(1): 189-204.

Misztal, B. 2002. Informality: Social theory and contemporary practice: Routledge.

Morand, D. A. 1995. The role of behavioral formality and informality in the enactment of bureaucratic versus organic organizations. Academy of Management Review, 20(4): 831-872. 
North, D. C. 1990. Institutions, institutional change and economic performance. Cambridge: Cambridge university press.

O’Reilly, C.A. \& Tushman, M.L. 2013. Organizational ambidexterity: Past, present, and future,, Academy of Management Perspectives, 27(4): 324-338.

Peng, M. W. 2003. Institutional transitions and strategic choices. Academy of Management Review, 28(2): 275-296.

Peng, M. W., \& Heath, P. S. 1996. The growth of the firm in planned economies in transition: Institutions, organizations, and strategic choice. Academy of Management Review, 21(2): 492-528.

Peng, M. W., \& Zhou, J. Q. 2005. How network strategies and institutional transitions evolve in Asia. Asia Pacific Journal of Management, 22(4): 321-336.

Poppo, L., \& Zenger, T. 2002. Do formal contracts and informal governance function as substitutes or complements? Strategic Management Journal, 23(8): 707-725.

Raisch, S., J. Birkinshaw. 2008. Organizational ambidexterity: Antecedents, outcomes, and moderators. Journal of Management, 34(3): 375-409.

Sharratt, D., Brigham, B. H., \& Brigham, M. 2007. The utility of social obligations in the UK energy industry. Journal of Management Studies, 44(8): 1503-1522.

Smith, W. K., \& Lewis, M. W. 2011. Toward a theory of paradox: A dynamic equilibrium of organizing. Academy of Management Review, 36(2): 381-403.

Welter, F. 2011. Contextualizing entrepreneurship-conceptual challenges and ways forward. Entrepreneurship Theory and Practice, 35(1): 165-184.

Yin, R. K. 2003. Case study research: Design and methods (3rd ed.). Newbury Park, CA: Sage.

Zhang, Z., Wan, D., Jia, M., \& Gu, L. 2009. Prior ties, shared values and cooperation in public-private partnerships. Management and Organization Review, 5(3): 353-374. 
Table 1. Description of cases

\begin{tabular}{|c|c|c|c|c|c|c|}
\hline Firm Name & Industry & $\begin{array}{l}\text { Returnee / Local } \\
\text { Firm }\end{array}$ & $\begin{array}{l}\text { Founding } \\
\text { Year }\end{array}$ & $\begin{array}{l}\text { Positions (Returnee/Local } \\
\text { Background) \& Numbers of Informants }\end{array}$ & $\begin{array}{l}\text { Returnee Founders' } \\
\text { Overseas Experience } \\
\text { (Average) }\end{array}$ & $\begin{array}{l}\text { Number of } \\
\text { Interviews }\end{array}$ \\
\hline R1-Energy & New energy & Returnee & 2009 & $\begin{array}{l}\text { President (R): } 1 \\
\text { VPs (R): } 2 \\
\text { CMO (L): } 1\end{array}$ & 10 years & 7 \\
\hline R2-Biotech & Biotech & Returnee & 2007 & $\begin{array}{l}\text { President (R): } 1 \\
\text { Vice President (R): } 1 \\
\text { CTO (R): } 1 \\
\text { Administrative director (L): } 1\end{array}$ & 13 years & 4 \\
\hline R3-Biotech & Biotech & Returnee & 2009 & $\begin{array}{l}\text { President (L): } 1 \\
\text { CEO (R): } 1 \\
\text { VPs (R): } 2 \\
\text { Director of R\&D (R): } 1 \\
\text { CMO (L): } 1\end{array}$ & 16 years & 8 \\
\hline L1-Energy & New energy & Local & 1999 & $\begin{array}{l}\text { President (L): } 1 \\
\text { CEO (L): } 1 \\
\text { VPs (L): } 2 \\
\text { CTO (L): } 1 \\
\text { Strategy Consultant (L): } 1\end{array}$ & None & 9 \\
\hline L2-Energy & New energy & Local & 2009 & $\begin{array}{l}\text { President (L): } 1 \\
\text { COO (L): } 1 \\
\text { CTO (L): } 1 \\
\text { Assistant President (L): } 1\end{array}$ & None & 8 \\
\hline L3-Biotech & Biotech & Local & 2002 & $\begin{array}{l}\text { President (L): } 1 \\
\text { CTO (L): } 1 \\
\text { CEO (L): } 1 \\
\text { CMO (R): } 1\end{array}$ & None & 9 \\
\hline
\end{tabular}

Note: (R) represents returnee entrepreneur / top manager; (L) represents local entrepreneur / top manager. 


\begin{tabular}{|c|c|c|c|c|c|c|}
\hline & \multicolumn{2}{|c|}{ Customer Relationships } & \multicolumn{2}{|c|}{ Public Relationships } & \multicolumn{2}{|c|}{ R\&D Collaborative Relationships } \\
\hline & $\begin{array}{l}\text { Formal-Informal } \\
\text { Ratio (by informant) }\end{array}$ & \begin{tabular}{|l|}
$\%$ of Formality \\
(from coding) $^{2}$
\end{tabular} & $\begin{array}{l}\text { Formal-Informal Ratio } \\
\text { (by informant) }\end{array}$ & $\begin{array}{l}\text { \% of Formality } \\
\text { (from coding) }^{2}\end{array}$ & $\begin{array}{l}\text { Formal-Informal Ratio (by } \\
\text { informant) }\end{array}$ & $\begin{array}{l}\text { \% of Formality } \\
\text { (from coding) }^{2}\end{array}$ \\
\hline Returnee & 9:1 (R1-Energy) & 66.7\% (R1-Energy) & 8:2 (R1-Energy) & 60.0\% (R1-Energy) & 7:3 (R1-Energy) & 71.4\% (R1-Energy) \\
\hline & 8:2 (R2-Biotech) & 83.3\% (R2-Biotech) & 8:2 (R2-Biotech) & 72.7\% (R2-Biotech) & 9:1 (R2-Biotech) & $66.7 \%$ (R2-Biotech) \\
\hline & 7:3 (R3-Biotech) & 53.8\% (R3-Biotech) & 6:4 (R3-Biotech) & 63.6\% (R3-Biotech) & 6:4 (R3-Biotech) & (R3-Biotec \\
\hline Local & 4:6 (L1-Energy) & 15.8\% (L1-Energy) & 4:6 (L1-Energy) & \% (L1-Energy) & 4:6 (L1-Energy) & (L1-Energy) \\
\hline & 4:6 (L2-Energy) & $25.0 \%$ (L2-Energy) & 1:9 (L2-Energy) & $11.1 \%$ (L2-Energy) & 3:7 (L2-Energy) & 33.3\% (L2-Energy) \\
\hline & 3:7 (L3-Biotech) & 33.3\% (L3-Energy) & 2:8 (L3-Biotech) & 33.3\% (L3-Biotech) & 2:8 (L3-Biotech) & $30.0 \%$ (L3-Biotech) \\
\hline $\begin{array}{l}\text { Stronger } \\
\text { emphasis } \\
\text { on } \\
\text { Formality } \\
\text { of Returnee } \\
\text { Firms }\end{array}$ & \multicolumn{2}{|c|}{$\begin{array}{l}\text { 'Competence is the most critical element in } \\
\text { achieving the deal. Personal connections } \\
\text { generate the possibilities to gain access to the } \\
\text { customers. But it is our distinctive competence } \\
\text { that turned the "possibility" into "reality"'. } \\
\text { (President of R1-Energy) } \\
\text { 'Trust is a kind of relationship. But ultimately, } \\
\text { you have to offer your customer quality and } \\
\text { service'.(CEO of R3-Biotech) }\end{array}$} & \multicolumn{2}{|c|}{$\begin{array}{l}\text { 'We didn't want to spend time on building close } \\
\text { relationships with government. We tried to avoid } \\
\text { it. Building close relationships with the } \\
\text { government or public stakeholders may distract } \\
\text { our focus from innovation'. (President of } \\
\text { R2-Biotech) } \\
\text { 'Having political connections do not mean } \\
\text { superior resources. Entrepreneurs are pursuing } \\
\text { efficiency, which is judged by the market } \\
\text { performance'. (President of R3-Biotech) }\end{array}$} & \multicolumn{2}{|c|}{$\begin{array}{l}\text { 'We mainly relied on explicit and detailed contracts to } \\
\text { manage R\&D collaborations at the early stage. Things } \\
\text { needed to be made very clear such as how to spend } \\
\text { money, how to distribute the profits and when to } \\
\text { complete the milestone'. (President of R1-Energy) } \\
\text { 'At the beginning of entrepreneurship, we used both } \\
\text { explicit contracts and mutual trust to manage R\&D } \\
\text { collaboration. But we mainly rely on detailed and clear } \\
\text { contracts because it can better protect our interests'. } \\
\text { (President of R3-Biotech) }\end{array}$} \\
\hline $\begin{array}{l}\text { Stronger } \\
\text { emphasis } \\
\text { on } \\
\text { Informality }\end{array}$ & \multirow{2}{*}{\multicolumn{2}{|c|}{$\begin{array}{l}\text { 'Actually, if we compare our investment in } \\
\text { relationship marketing and product } \\
\text { improvement in early stage, we invested more } \\
\text { resources into building customer relationships } \\
\text { including harmonious channel relationships } \\
\text { and marketing activities, which did bring us } \\
\text { higher profit'. (VP of L1-Energy) } \\
\text { 'At the early stage of new venture, product } \\
\text { improvement has very little impact on sales. In } \\
\text { contrast, trust and personal relationships could } \\
\text { earn the first transaction and have greater } \\
\text { impact on sales'. (President of L2-Energy) }\end{array}$}} & \multirow{2}{*}{\multicolumn{2}{|c|}{$\begin{array}{l}\text { 'Through our early years, we didn't get explicit } \\
\text { support from the government like money and } \\
\text { projects. But we just kept reporting to the } \\
\text { government and communicating with the officials } \\
\text { actively, in order to achieve some implicit } \\
\text { support'. (VP of L1-Energy) } \\
\text { 'When you first communicate with the } \\
\text { government, they do not know how good your } \\
\text { technology is and how good your projects are. At } \\
\text { this stage, personal relationship is very important } \\
\text { and has the major effects. It refers to your ability to } \\
\text { communicate with the officials so as to convince } \\
\text { them'. (President of L2-Energy) }\end{array}$}} & \multirow{2}{*}{\multicolumn{2}{|c|}{$\begin{array}{l}\text { 'In our early R\&D collaborations, good collaborative } \\
\text { relationships and mutual trust played the dominant role } \\
\text { I think explicit contracts are formats, but trust anc } \\
\text { understandings are foundations'. (VP of L1-Energy) } \\
\text { 'In early collaborations, we mainly relied or } \\
\text { establishing common goals of developing the whol } \\
\text { industry. Interests are not enough to manage R\&D } \\
\text { instead we need a mission to guide the collaboration' } \\
\text { (President of L2-Energy) }\end{array}$}} \\
\hline $\begin{array}{l}\text { of Local } \\
\text { Firms }\end{array}$ & & & & & & \\
\hline
\end{tabular}

1. Formal-Informal Ratio represents the proportion of formal elements vs. the proportion of informal elements (sum of 10 ) used by each firm in the early stage.

2. \% of Formality represents the percentage of interview quotes coded as formal elements. 


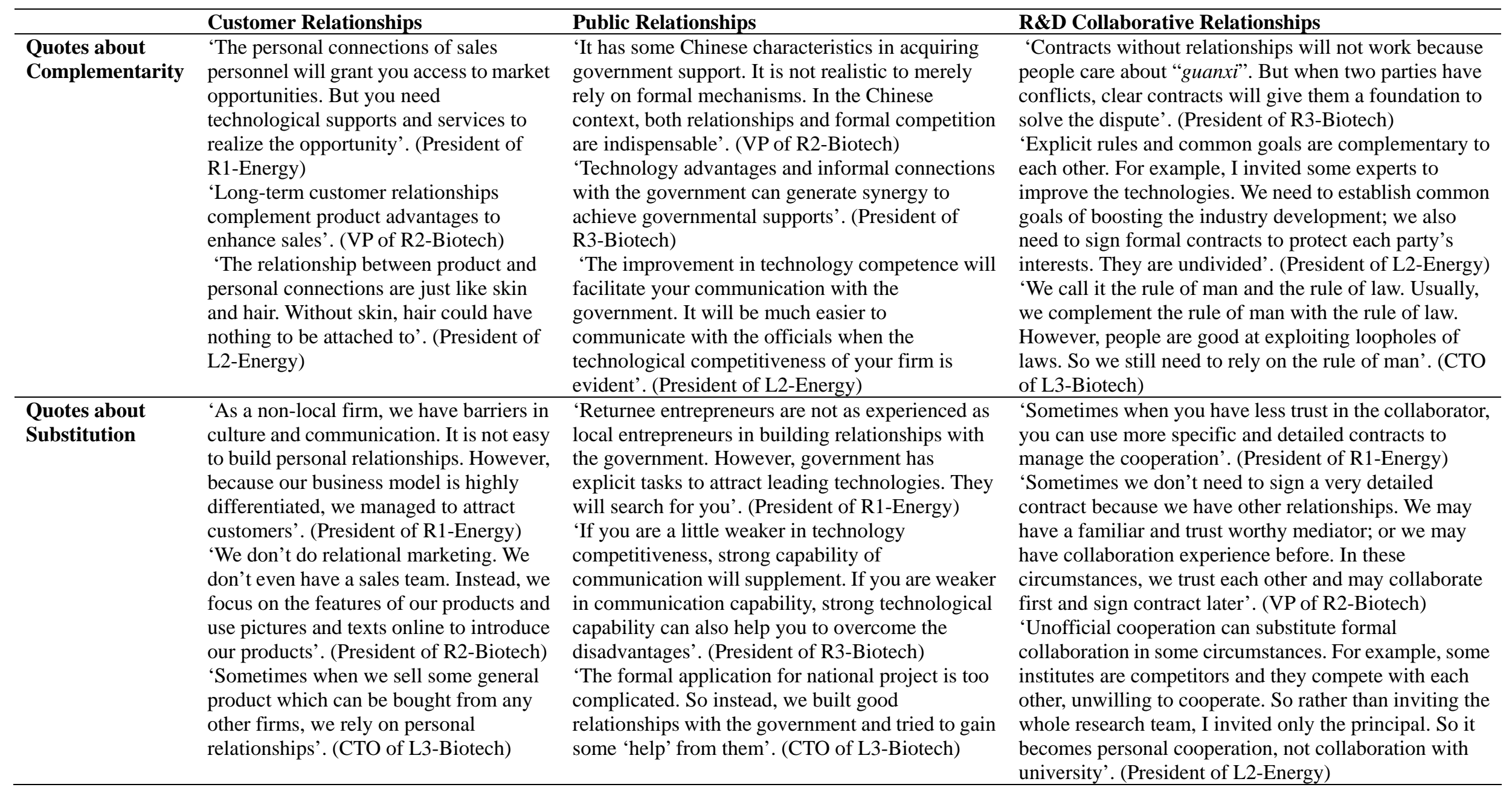


Table 4. Transitional balancing of returnee and local firms from the early state to later stages of venturing

\begin{tabular}{|c|c|c|c|}
\hline $\begin{array}{l}\text { Formality-Informality Ratic } \\
\text { (Early }^{1} \rightarrow \text { Later Stage }^{2)}\end{array}$ & Customer Relationships & Public Relationships & R\&D Collaborative Relationships \\
\hline Returnee Firms & $\begin{array}{l}9: 1 \rightarrow 8: 2 \text { (R1-Energy) } \\
8: 2 \rightarrow 6: 4 \text { (R2-Biotech) } \\
7: 3 \rightarrow 6: 4 \text { (R3-Biotech) }\end{array}$ & $\begin{aligned} & 8: 2 \rightarrow 7: 3 \text { (R1-Energy) } \\
& 8: 3 \rightarrow 7: 3 \text { (R2-Biotech) } \\
& 6: 4 \rightarrow 7: 3\left(\text { R3-Biotech }{ }^{3}\right)\end{aligned}$ & $\begin{array}{c}7: 3 \rightarrow 6: 4 \text { (R1-Energy) } \\
9: 1 \rightarrow 7: 3 \text { (R2-Biotech) } \\
6: 4 \rightarrow 7: 3\left(\text { R3-Biotech }^{3}\right) \\
\end{array}$ \\
\hline Local Firms & $\begin{array}{l}4: 6 \rightarrow 6: 4 \text { (L1-Energy) } \\
4: 6 \rightarrow 7: 3 \text { (L2-Energy) } \\
3: 7 \rightarrow 7: 3 \text { (L3-Biotech) }\end{array}$ & $\begin{array}{l}4: 6 \rightarrow 6: 4 \text { (L1-Energy) } \\
1: 9 \rightarrow 4: 6 \text { (L2-Energy) } \\
2: 8 \rightarrow 4: 6 \text { (L3-Biotech) }\end{array}$ & $\begin{array}{l}4: 6 \rightarrow 6: 4 \text { (L1-Energy) } \\
4: 6 \rightarrow 7: 3 \text { (L2-Energy) } \\
2: 8 \rightarrow 4: 6 \text { (L3-Biotech) }\end{array}$ \\
\hline Returnee Firms & $\begin{array}{l}\text { 'Local people know a lot more about the } \\
\text { local policies and market environment } \\
\text { than returnee entrepreneurs. Starting from } \\
\text { last year, we recruited more local sales } \\
\text { team to build customer relationships'. } \\
\text { (President of R1-Energy) } \\
\text { 'Returnees are not familiar with how to } \\
\text { communicate and build relationships with } \\
\text { domestic customers. We are now } \\
\text { recruiting a local sales team to improve } \\
\text { customer relationships'. (CEO of } \\
\text { R3-Biotech) }\end{array}$ & $\begin{array}{l}\text { 'We want to promote communication and } \\
\text { reciprocal learning through this international } \\
\text { competition platform. We can build public image, } \\
\text { promote collaboration in the new energy industry } \\
\text { through this event'. (President of R1-Energy) } \\
\text { 'We started to make our company visible to the } \\
\text { publicity For example, in March, } 2011 \text { our } \\
\text { returnee CEO has an interview report on Beijing } \\
\text { Daily. It was a beginning of our publicity'. (CMO } \\
\text { of R3-Biotech) }\end{array}$ & $\begin{array}{l}\text { 'We gradually relied more on other forms of } \\
\text { collaborations other than formal R\&D projects. For } \\
\text { example, in our collaboration with a hospital, we } \\
\text { communicated a lot and collaborated without } \\
\text { contracts at the early stage because we both trust the } \\
\text { principal in the project'. (VP of R2-Biotech) } \\
\text { 'After years of development, we have gradually } \\
\text { established our reputation and brand asset, based on } \\
\text { which our collaboration with other institutes are } \\
\text { more accessible and efficient'. (President of } \\
\text { R1-Energy) }\end{array}$ \\
\hline Local Firms & $\begin{array}{l}\text { "We began to focus more on improving } \\
\text { the technology of our products. We } \\
\text { needed to transfer the advantage of } \\
\text { marketing and profitability into R\&D and } \\
\text { technological capabilities." (President of } \\
\text { L1-Energy) } \\
\text { "After about four years, we began to } \\
\text { emphasize on the improvements of } \\
\text { products and services, after we had } \\
\text { accumulated some experience in the } \\
\text { market." (President of L3-Biotech) }\end{array}$ & $\begin{array}{l}\text { "As our technology developed, the impact of } \\
\text { advanced technology on governmental supports } \\
\text { is growing. Now I don't need to personally } \\
\text { communicate with the government officials and } \\
\text { maintain the relationship very often" (President } \\
\text { of L2-Energy) } \\
\text { "We have just passed the authentication of the } \\
\text { government that our reports of the industry is } \\
\text { approved by the government. We are now one of } \\
\text { the few national enterprise technology centers in } \\
\text { the province." (President of L1-Energy) }\end{array}$ & $\begin{array}{l}\text { "As the firm is having more and more R\&D } \\
\text { collaborations, we rely more on explicit contracts } \\
\text { and rules to manage R\&D collaborations. For } \\
\text { example, we collaborated with a foreign institute. } \\
\text { And the main mechanism we used to manage the } \\
\text { collaboration is contract." (President of L2-Energy) } \\
\text { "For the first two years, we played the edging ball } \\
\text { to leverage the brand asset of the University. It was } \\
\text { not formally proved the University. After the first } \\
\text { two years, we were not using the University's name } \\
\text { any more. It's better to stick to the formal } \\
\text { agreement." (President of L1-Energy) }\end{array}$ \\
\hline
\end{tabular}

1. Formal-Informal Ratio at Early Stage represents the proportion of formal vs. informal elements (sum of 10) used by each firm at the early stage.

2. Formal-Informal Ratio at Later Stage represents the proportion of formal vs. informal elements (sum of 10) used by each firm in 2013.

3. R3-Biotech is planning to go public. As the President told us, "we need to be more formal as we are going public". Therefore, we treated R3-Bioteh as a special case. 
Table 5. Emphasis on synergy between returnee and local firms

\begin{tabular}{|c|c|c|}
\hline Emphasis on Synergy & Returnee Firms & Local Firms \\
\hline $\begin{array}{l}\text { Customer } \\
\text { Relationships }\end{array}$ & $\begin{array}{l}\text { 'After several years, we have accumulated some experience in the } \\
\text { local market. Then we started to make efforts to establish our brand } \\
\text { and reputation because it will complement our technological } \\
\text { advantages and facilitate to gain financial and human resources'. } \\
\text { (President of R1-Energy) } \\
\text { 'We have placed primary emphasis on technological capability } \\
\text { building. However, now we need to strengthen our marketing capacity } \\
\text { to sell products. We have to complement the product advantages with } \\
\text { sales capacity'. (President of R3-Energy) }\end{array}$ & $\begin{array}{l}\text { 'It will be much easier to for our sales force to sell products if the products } \\
\text { and services are improved. Ultimately, customers are paying money to } \\
\text { satisfy their needs. Although it is important to use 'guanxi' to start the } \\
\text { access the customers, in the end we need to enhance the quality of our } \\
\text { products and services'. (President of L3-Biotech) } \\
\text { 'Ultimately we are satisfying customer's needs. So we must improve our } \\
\text { technologies and products to meet customers' demands'. (VP of } \\
\text { L1-Energy) }\end{array}$ \\
\hline
\end{tabular}


Figure 1. Data coding scheme

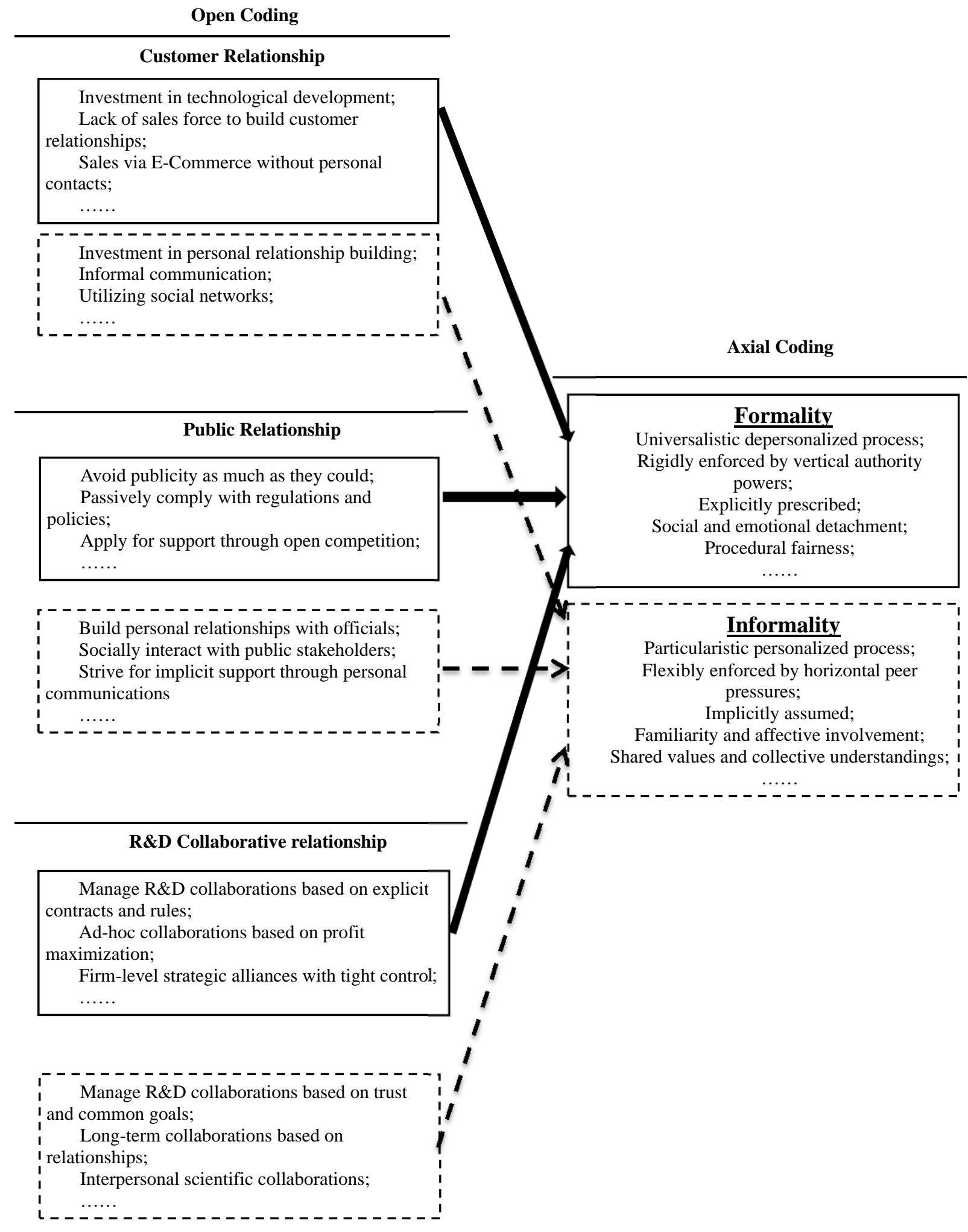

Note: The solid line boxes are for formal elements and the dotted line boxes are for informal elements. 
Daomi Lin (lindaomi.pku@gmail) is Assistant Professor of Management at Lingnan College, Sun Yat-sen University. She received Ph.D. from Guanghua School of Management, Peking University. Her research focuses on return migration, knowledge spillovers and entrepreneurship in emerging economies. She achieved the Third Annual IACMR Li Ning Dissertation Proposal Grants in 2012.

Jiangyong Lu (lujiangyong@gsm.pku.edu.cn) is Associate Professor of Strategy at Guanghua School of Management, Peking University. He received PhD from the University of Hong Kong. His research examines internationalization, innovation and entrepreneurship in emerging economies and has been published in Strategic Management Journal, Journal of International Business Studies and Journal of International Economics among others.

Peter Ping Li (pli.int@cbs.dk) received his Ph.D. from George Washington University and is Professor of Chinese Business Studies at Copenhagen Business School, Denmark. Adopting the unique Chinese frame of Yin-Yang Balancing with the holistic, dynamic and duality dimensions, his research focuses on integrating the Western theories with the indigenous perspectives of the East. He is the editor-in-chief of Journal of Trust Research and also serves on the editorial boards of six major journals.

Xiaohui Liu (X.Liu2@lboro.ac.uk) is Professor of International Business and Strategy at the School of Business and Economics, Loughborough University. She received her $\mathrm{PhD}$ from the University of Birmingham (UK). Her main research interests include knowledge spillovers, human mobility, innovation and the internationalisation strategies of firms from emerging economies. She has published widely and is senior editor of Management and Organization Review and advisory editor of Research Policy. 